\title{
LINGUISTIC MANIPULATIVE TECHNIQUES IN ADVERTISING SLOGANS OF FAST FOOD RESTAURANTS
}

\author{
Nataliia Dobzhanska-Knight \\ ndobzhanska@ukr.net \\ Khrystyna Voitko \\ krisvoitko@gmail.com \\ Lesya Ukrainka Eastern European National University, Ukraine
}

Received November 29, 2017; Revised December 3, 2017; Accepted December 12, 2017

\begin{abstract}
The article deals with the notion of manipulation in advertising slogans of fast food restaurants. It focuses on techniques and means of language influence on the recipient. The article shows results of the study of 239 advertising slogans of fast food resta urants in Englishspeaking countries (a total number of 104 companies). Different language patterns which are used in advertising slogans and aimed at persuasion of customers on the subconscious level, are defined and analyzed; among them the most numerous are language patterns which create statements with distortions, deletions, and generalizations manifesting themselves in a variety of forms. The research also describes manipulative language patterns specifically related to advertising, such as unique selling proposition or life values. The authors also show quantitative proportions of the use of each pattern, as well as patterns used by the most successful and less successful restaurants. The most frequent of the manipulative language patterns are lost performatives, mind reading, and comparisons. The techniques of life values, mind reading, and antithesis are more common in advertising slogans of top restaurants compared to less popular ones. Individual slogans frequently manifest the use of more than one linguistic pattern of manipulation.
\end{abstract}

Keywords: manipulation, advertisement, distortion, deletion, generalization, presupposition, metaphor.

Добжанська-Найт Наталія, Войтко Христина. Лінгв істичні маніпулятивні засоби в рекламних слоганах ресторанів фаст-фуду.

Анотація. У статті досліджено поняття ман іпуляції в рекламних слоганах ресторан ів фаст-фуду. Зосереджено увагу на засобах та методах мовного впливу на реципієнта. Праця показує результати дослідження 239 рекламних слоганів ресторанів фаст-фуду в англомовних країнах (всього 104 компанії). Розглянуто особливості мовних шаблон ів, які часто використовуються для підсвідомого впливу на клієнтів, серед них найчисленнішими $\epsilon$ лінгвальні засоби - твердження із впливом на підсвідомість, що містять викривлення, узагальнення та упущення, які виявляються у різноманітних формах. Дослідження також містить опис маніпулятивних мовних засобів, властивих рекламі: «унікальна торгова пропозиція» та «підлаштування під цінності». Автори також демонструють кількісні пропорції використання кожного засобу, а також порівнюють слогани популярних та менш популярних ресторан ів швидкої їжі. Найхарактернішими $\epsilon$, зокрема, такі мовні засоби: втрачений перформатив, «читання думок» та порівняння. Прийоми «підлаштування під цінності», «читання думок» та антитеза характерніші для рекламних слоганів топ-ресторанів, у порівнянні з менш популярними компан іями. В одному слогані часто використано понад один лінгвальний засіб ман іпуляції.

Ключові слова: маніпулящія, реклама, спотворення, упущення, узагальнення, пресупозиція, метафора. 


\section{Introduction}

Using manipulative techniques aimed at convincing a potential buyer to use the advertised goods and services has always been an important factor in advertising. As is well-known, persuading a person to become a business's customer is one of the goals of advertising. In recent decades, as we can observe, with the ever-growing competition in the world of business, the number of such techniques has increased in number as well as in variety.

Manipulative language patterns have been extensively discussed in various academic publications. In particular, researchers discuss various types of manipulation, such as 'plain folks' techniques (Kalishchuk, 2012), manipulative techniques in commercial and political advertisements (Kutuza, 2006), deceitful advertising, fallacious arguments, emotive persuasion in advertising (Danciu, 2014), mnemotechnical devices of manipulation which include rhyme, rhythm, alliteration and assonance, persuasion on the level of lexicology and morphology (mainly adjectives, epithets, numerals), intertextuality, formation of new words and phrases with the help of shortening, affixation blending, and compounding (Lapšanská 2006), conversion, divergent spelling, antisthecon, conversion, anthimeria, block language, and rhetorical devices (Romanenko, 2014).

The question of attention-seeking devices in advertising on phonological, lexical, morphological and other language levels has been raised in works of scholars specializing in economics (Danciu, 2014), and psychology (Dilts, 2008) as well as linguistics (Lapšanská, 2006; Romanenko, 2014; Kutuza, 2006). In particular, linguistic works emphasize online advertising (Romanenko, 2014), give a broader view of manipulative devices in advertising and politics (Kutuza, 2006), and focus on the study of stylistic peculiarities of advertising slogans (Lapšanská, 2006). Despite the extensive studies of manipulative techniques, research into the use of such techniques in advertising slogans of fast food restaurants has not been conducted yet.

\section{Methods}

The question of a negative effect of fast food on human health has been extensively covered in mass media, supported by numerous conclusions of doctors, dieticians and scientists. Nevertheless, the popularity of such facilities is still beyond any doubt. We believe that the reason for commercial success of such food is not limited to the qualities of the food itself, the effect of advertising cannot be excluded. Therefore, we decided to analyze 239 advertising slogans of popular networks of fast food restaurants in English-speaking countries (a total of 104 restaurants), gathered from the companies' websites (as well as other online sources), and the manifestation of manipulative techniques in the form and content of such slogans.

The goal of our research was to analyze the form and the content of advertis ing slogans of fast food restaurants, in respect to their intention and ability to incite a potential customer to buy their products. Among the tasks of the research we saw:

defining the types of manipulative techniques used in advertising slogans of fast food restaurants; analyzing the proportion in which manipulative techniques are used in such slogans; defining the prevailing, or most popular, types of linguistic 
manipulation in the analyzed slogans; and comparing the manipulative language patterns in the slogans of the most popular fast food restaurant networks (according to the version of QZS Journal) to those of less popular ones.

In analyzing the use of manipulative patterns and their frequency in advertising slogans, we based our research on the classification of manipulative patterns associated with deletion, distortion and generalization processed in the human mind (Bandler, Grinder, 1975:14). Creating such patterns with the purpose of influencing an addressee would potentially have an effect on the addressee's subconscious mind. We have also analyzed the use of other language patterns aimed at a person's subconscious mind: presuppositions, tag questions, embedded commands, double binds, antithes is, and metaphors, all of which are widely used in advertising slogans (Burton and Ready, 2010:255-258). These language patterns have been defined and extensively explained, including the use of certain language markers, but the task of our research is to recognize the above-mentioned patterns in advertising slogans of fast food restaurants, as well as analyze their implications and possible ways of influencing a potential customer.

\section{Results and Discussion}

The dictionary definitions of advertising, as well as slogans, include manipulation as a means of achieving the seller's goal. According to the Longman dictionary, advertising is defined as telling people publicly about a product or service in order to persuade them to buy it (Longman Dictionary, 2017). A Business dictionary provides us with the next definition: 'The activity or profession of producing information for promoting the sale of commercial products or services' (Business dictionary.com, 2017). The Cambridge dictionary defines advertising as the business of trying to persuade people to buy products or services (Cambridge Dictionary, 2017).

The dictionary definition of manipulation supports the idea of using certain means (including language) for the purpose of inducing a certain person/ or persons to contribute to the manipulator's goal. Oxford Learner's Dictionary indicates that it is the behavior that controls or influences somebody, often in a dishonest way such that they do not realize it (Oxford Dictionary, 2017). Dictionary.com views the notion of manipulation as the way of exerting skillful influence on a person (Dictionary.com, 2017).

In analyzing the advertis ing slogans of fast food restaurants, we have observed numerous language patterns which are used to persuade the customers to pay money for advertised products or services. Among them we can find three main models comprising language patterns to influence a person's subconscious mind and bypass the resistance of the conscious mind. These three models are distortion, deletion, and generalization, which reflect the corresponding processes in the human brain (Bandler, Grinder, 1975:14).

Generalization is the mechanism that allows us to separate some parts of the unique model so that it leads to the creation of the whole category (Bandler, Grinder 1975: 80). This group includes the use of universal quantifiers and modal operations in the language. 
Universal quantifiers, such as everyone, usually, always, never (Burton and Ready, 2010:241), create the impression that no exception is possible. Let us look at some examples of advertising slogans using universal quantifiers. One of the fast food restaurants Five Guys created the following slogan: 'Always fresh. Never frozen. Famous Burgers and Fries' ("Five Guys Prices" 2017). In this case the adverbs always and fresh state the fact that the food of that restaurant is cooked only in a superb way. Another chain of fast food restaurants, Denny's, uses the slogan 'America's Diner is Always Open!' (Perrotte, 2015). The word always puts the emphasis on the readiness of the restaurant to take orders 24 hours per day.

Modal operators of necessity manipulate the recipient to create the impression that the recipient cannot decline the offer as there is no choice (must, should, have) (Burton and Ready, 2010:241). In the advertising slogans of Steak 'n Shake 'In Sight It Must Be Right' (Hunt, 2014) and Subway 'The Way A Sandwich Should Be' (Subway, 2017) the words must and should miss the information about other options.

Modal operators of possibility, such as can, can't (Burton and Ready, 2010: 241), manipulate the very idea of something being possible or impossible for somebody. For example, in advertisement mottos of McDonald's 'Nobody can do it like McDonald's can' (Wang, 2006) and Chuck E. Cheese's 'Where a kid can be a kid' (Fast Food, 2017) the modal operators of possibility point out the fact that something is possible (McDonald's can, a kid can) and something is not (nobody can), without supporting facts or evidence to prove the bold statement.

Deletion is a form of manipulation which omits certain pieces of information of the deep language structure (Vaknin, 2008:604), thus creating an incomplete picture where the truth which could create certain doubt in the recipient's mind, is hidden. This group encompasses the following language patterns:

Comparative deletion states the comparison but misses the information about what or who is compared with (Vaknin, 2008:607). In slogans of restaurants Papa John's Pizza 'Better Ingredients. Better Pizza' (Famous Restaurant Slogans, 2017) and Eagle boys 'Bigger, Better' ("Eagle Boys Pizza Seeks, 2017), it is not clear why the advertisers define their products as something better or bigger. We can use the questions 'Bigger than what? Better that what?' to confute the advertisement.

Unspecified referential index, where the person or thing is not specified (Vaknin, 2008:606). The fast food restaurant Church's Chicken uses the slogan 'You bring it home' (Restaurant Slogans, 2017). The pronoun it does not specify the information of what this motto is about. In another slogan of McDonalds 'We love to see you smile' (Rella, 2016) pronouns we and you do not define the person 'who smiles' and 'who loves'. In this way these kinds of slogan can be applied directly to every customer.

Simple deletion misses out the part of the information that intended to be said (Burton and Ready, 2010:253). The slogan 'Makin' it great again and again' (Pizza Hut, 2017) (Pizza Hut) does not state any data that can reveal what the slogan meant. The question 'Who is making it again and again?' defines the aforementioned language pattern. 
Unspecified verbs leave out the information about how the action is carried out (Burton and Ready, 2010:253). For example, the fast food company KFC uses the slogan 'We do chicken right' (Best Slogans, 2017). The verb do does not specify the information about how exactly the company works with a chicken but this technique evokes people's desire to make an order in this restaurant.

Nominalization is a verb that serves in a sentence as a noun. These are words that cannot be seen, touched or heard (Vaknin, 2008:177). The company Papa Murphy's had chosen the slogan 'Love at 425 degrees' (Papa Murphy's Cowboy, 2013). In this case the word love functions as a noun and it is directed to the audience's unconscious; in other words, the pattern is used to induce people to eat pizza at Papa Murphy's. In the next slogan of McDonald's, 'A Visit to McDonald's makes your day' (Wang, 2006), the noun a visit also performs the function of nominalization that states the fact that if a person visits the advertised restaurant, he will not regret it.

Distortion is a technique that changes the accuracy of the intended message (Vaknin 2008: 608). The following language patterns belong to this group:

Complex equivalence is the connection of two actions that are not in any way related to each other (Vaknin, 2008:614). For instance, between the parts of the Burger King's slogan 'America Loves Burgers and We're America's Burger King' ("Restaurant Slogans", 2017.) there is no real connection, but advertisers make customers believe that American citizens love the burgers only of that restaurant. One more example is the slogan of Harry Ramsden's, 'People who love food love Harry Ramsden's' (Fish and chips slogans, 2017). This slogan builds a stable connection between Harry Ramsden's and delicious food.

Mind reading is the method that shows that somebody knows what other people think or know. Such utterances can be confuted with the help of the question 'How do you know that?' (Vaknin, 2008:611). This technique can be found in the following slogans of fast food restaurants: Jimmy Johns: 'Your Mom Wants You To Eat At Jimmy John's!' (Restaurant Slogans, 2017.) and Pret a Manger: 'Your Favorite Pret Foods now in Salad Form' (Pret a Manger, 2017). With the help of this language pattern it is possible to persuade a person that the company knows best regard ing what a client really wants.

Cause-effect is a language pattern that shows the result of the cause (Vaknin, 2008:612). The slogan of the company Krispy Kreme 'Bring a box. Bring a joy' (Waiz, 2017) implies the idea that a person can become happy when he buys a product from that restaurant. If one divides the Extreme Pita's slogan 'Eat good. Feel good' (Eat good, 2016) into two parts: 'eat good' - cause, 'feel good' - effect, it can be noticed that the message is that a person feels good only in the case his or her food is well-prepared, and Extreme Pita presents this opportunity.

Lost performatives are judgements that are based on the belief that if it is obligatory for one person, then it must be correct for other people (Vaknin, 2008:602). In order to confute this judgement, the questions 'Who thinks that it is so? For whom?' are asked. For instance, in one of the slogans of Domino's Pizza 'Bad Andy, Good Pizza' (Smaktakula, 2011) the information about the person, who considers that this pizza is good, is missed. The question 'Who is it good for?' 
defines this language pattern in the slogan of Sonic Drive-In, 'Not just good... it's Sonic good' (Restaurant Slogans, 2017).

In the process of analyzing the advertising slogans of fast food restaurants we have observed the extensive use of other persuasion techniques aimed at inducing a potential customer to buy their products and services. Among them, namely, are presuppositions, tag questions, embedded commands, double binds, antithes is and metaphors, all of which are widely used in advertising slogans (Burton and Ready, 2010:255-258).

A tag question is a short question that is added at the end of a question. They are used for softening the resistance (Burton and Ready, 2010:255). In the slogan of Rax Roast Beef restaurant: 'I'd Rather Rax, Wouldn't You?' (Restaurants, 2013), a tag question was used deliberately in order to distract people's attention and direct the information to their unconsciousness.

Embedded commands are used in questions or other sentences that send the information to the subconscious and the conscious mind cannot block it (Burton and Ready, 2010:255). An example of such commands can be slogans of the Hardee's restaurant chain 'Come on Home' (Famous restaurant slogans, 2017) and Dairy Queen, 'Do something different' (Restaurant Slogans, 2017). The phrasal verb come on and the verb $d o$ imply the idea of commands.

Double binds are utterances that give people the opportunity to choose but no real option is available (Burton and Ready, 2010:255). Burger King Corporation used the slogan 'Sometimes you've got to break the rules' (Restaurants, 2017) in which the word sometimes states the fact that if not today, at least some time in the future a customer must buy something in that restaurant of junk food and 'break the rule' of eating healthy food.

Antithesis is the process that can be found in sentences with quite different parts. If one of the parts is intensified, then a bigger difference can be revealed between these two parts (Horyn, 2004:275). For example, in the slogan of Church's Chicken 'Big Pieces, Little Prices' (Restaurant Slogans, 2017), it is stated that their menu is very cheap but even in this case people can buy a lot of food.

Metaphors enable the advertiser to change the main idea of the information so that the customer does not notice it. Metaphor sends directions to a person's unconscious so that they cannot object to that information later (Alder, 2002:42). An example of this technique is the slogan of Arby's restaurant, 'It's Good Mood Food' (Restaurant Slogans, 2017). Firstly, it informs about the ability to be in a good mood, but then the word food is connected with the phrase good mood that directs people to the advertised restaurant.

Presupposition is the assumption that defines the original essence of the message (Burton and Ready, 2010:20-32). For example, the company Jack in the Box created the slogan 'We don't make it until you order it' (Fast food slogans, 2017). It has the following presupposition: 'in that restaurant the meal is cooked after taking the order, that's why it's always fresh there'. In the slogan 'Just like you like it' (Fast food slogans, 2017), that is used by Whataburger company, the main idea is the following: 'in that restaurant everyone can find something tasty'. 
Every year the specialists in marketing improve old methods and discover new ones in order to sell more products. Usually such techniques as life values, truisms and unique selling propositions are used.

Life values is the usage of notions that are important for the audience: home, children, life, happiness, health, family, etc. In an advertisement a negative notion can be used together with a positive one and as a result the whole idea of the text can have a different meaning (Hesiuk, 2014:124). An example of this can be a slogan of the company Krispy Kreme Doughnuts, 'Happy All Around' (Waiz, 2017). In this case people may believe that in that restaurant they can be always happy, because such a value as happiness is used. The company Boston Pizza used in its slogan the value of friendship: 'You're among friends at Boston Pizza' (Smith 2017). This slogan makes people believe that in this restaurant they will never feel 'like a fish out of water'.

A truism is a judgement that cannot be objected to (Colbert, 2012:114). A slogan of the company IHOP 'Come hungry. Leave happy' (Rella, 2016) states a common truth (not limited to any restaurant) that a person naturally feels happy after satisfying their bodily need to eat. In the slogan, however (which advertises a particular company), the implication is that the happiness comes as a result of having a meal at a restaurant of their company. cannot be denied, because usually people come to the restaurant to eat and after that they can feel the happiness. Baja Fresh's slogan 'Eat Well. Live Fresh' (Fast Food Slogans, 2017) - is one more example of the usage of truism, because it implies a natural connection between the quality of life and eating well. In addition, the word fresh often refers to food, which may plant an idea in a person's mind that the food is also fresh and healthy in the company's restaurants. At the same time, the slogan omits the information that the company specializes in making fast food, which almost always means junk food, but the audience's unconscious does not notice that and, as a result, people want to eat at this restaurant.

A unique selling proposition is a concept that is based on the given information about the company so that the opponents cannot or have not offered that proposition yet (Ciotti, 2013). For example, the slogan of the company Taco Bell, 'Why Pay More!?' (Restaurant Slogans, 2017), attracts a customer's attention to the cheap menu and that evokes the desire to make an order in that restaurant. A lot of restaurants offer good food but not all of them are available at night. The restaurant Wendy's gives this opportunity: 'Eat Great Even Late' (10+ Wendy's Slogans, 2017). This proposition distinguishes this restaurant from another.

In slogans of popular companies, we have found nominalizations $(6.45 \%)$, comparisons (14.52\%), simple deletions (4.83\%), and unspecified verbs $(4.83 \%)$. In the slogans of restaurant chains that are less popular, the following was found: nominalizations $(5.45 \%)$, comparisons (16.36\%), simple deletions (3.64 \%), unspecified verbs $(3.64 \%)$. As for the method of generalization, the amount of speech patterns in the slogans of all considered companies is almost the same. If we take into account the method of distortion, it was found that the frequency of usage of lost performatives in slogans of well-known restaurants is shorter than in those of 
less popular restaurants: $50.00 \%$ and $67.67 \%$. The technique of mind reading is more frequently met in slogans of top companies $(27.14 \%)$ than in less popular restaurants $(13.33 \%)$.

The technique of antithesis is more often found in the slogans of less wellknown restaurants $(8.57 \%)$, while in the slogans of famous fast-food restaurants, the frequency of the usage of that language pattern is $4.23 \%$.

According to the results of the study of such techniques as truisms, life value and unique selling proposition, we have found that the frequency of the usage of 'unique selling proposition' is similar (24.00\%); 'life values' is more frequently found in slogans of famous restaurants $(65.00 \%)$, rather than in less popular restaurants (57.14\%); however, truisms are less common in slogans of top restaurants $(10.00 \%)$, in comparison with those of the less popular ones (19.05\%).

\section{Conclusions}

The study of 239 advertising slogans of popular networks of fast food restaurants in English-speaking countries (a total number of 104 restaurants) shows an extensive use of manipulative language patterns. Among them, the most frequent are the use of lost performatives, mind reading, and comparisons. Less frequent language patterns are truisms, antithesis, nominalisations, and unspecified verbs. Individual slogans frequently manifest the use of more than one linguistic pattern of manipulation, since the possibility of creating the most effective advertisement increases proportionally to the number of patterns used, while the use of only one method of persuasion seriously reduces such a possibility.

\section{References}

\section{Література}

Alder, H. (2002). Handbook of NLP: A Manual for Professional Communicators. New York: Routledge

Bandler, R, Grinder, J. (1975). The Structure of Magic ( $1^{\text {st }}$ edition). USA: Science \& Behavior Books.

Burton, K., Ready, R. (2010). Neuro-linguistic Programming for Dummies. West Sussex: Wiley

Ciotti, G. 5 Ways to Develop a Unique Selling Proposition Convince\&Convert. Dec. 2013. Retrieved from http://www.convinceandconvert.com/digital-marketing/5-ways-to-developa-unique-selling-proposition/

Colbert, B. (2012). From Ordinary to Extraordinary - How to Live An Exceptional Life. Ireland: Gill

Danciu, V. (2014). Manipulative marketing: persuasion and manipulation of the consumer through advertising. Theoretical and Applied Economics, 9(2), 19-34.

Гесюк Ю. Застосування нейролінгв істичного програмування в рекламі. Медіапростір. 2014, № 5. C. 122-126.

Горин С. НЛП: Техники россыпью. //Метафора экспромтом. Под ред. Н. Либман. М.: КСП+, 2004. С. 269-268.

Калішук Д. Психолінгвістичні прийоми мовленнєвого маніпулювання у політичному дискурсі «Гра у простонародність» // Вісник Харківського національного університету імені В.Н. Каразіна. 2012. Вып. 1022, № 71. С. 59-63.

Кутуза Н. Ман іпулятивні прийоми в рекламному та політичному дискурсах: лінгвістичні аспекти // Науковий вісник Херсонського державного університету. 2006. № 3. С. 285-288. 
Lapšanská, J. (2006). The language of advertising with the concentration on the linguistic means and the analysis of advertising slogans. Diploma thesis, Bratislava: Comenius University in Bratislava, Faculty of Education.

Romanenko, E. (2014). Linguistic analysis of on-line advertising in English. Bachelor thesis, Prague: Charles University in Prague, Faculty of education.

Vaknin, S. (2008). The Big Book of NLP Techniques. Charleston: BookSurge.

\section{References (translated and transliterated)}

Hesiuk, Y. (2014). Zastosuvannia neirolinhvistychnoho prohramuvannia v reklami [The usage of neurolinguistic programming in advertising]. Mediaprostir, 5, 122-126.

Horyn, S. (2004). NLP: Tehnyky rossypiu. [Writing techniques]. In: Metafora Expromtom, (pp. 269-268). N. Libman (ed). Moscow: KSP+.

Kalischuk, D. (2012). Psykholinhvistychni pryiomy movlennievoho manipuliuvannia u politychnomu dyskursi. "Hra u prostonarodnist" [Psycholinguistic Techniques of Speech Manipulation in Political Discourse. "Plain Folks"]. Journal of V.N.Karazin National University of Kharkiv, 1022(71), 59-63.

Kutuza, N. (2006). Manipuliatyvni pryiomy v reklamnomu ta politychnomu dyskursakh: linhvistychni aspekty [Manipulative techniques in advertisement and political discourse]. Informational-Methodical Journal of Kherson State University, 3, 285-288.

\section{Sources}

Advertising. 2017. In Business dictionary.com. Retrieved November 9, 2017, from http://www.businessdictionary.com/definition/advertising.html

Advertising. 2017. In Cambridge dictionary. com. Retrieved November 9, 2017, from https://d ictionary.cambridge.org/dictionary/english/advertising

Advertising. 2017. In Longman Dictionary of Contemporary English. Retrieved November 9, 2017, from https://www.ldoceonline.com/dictionary/advertising

Burger King Slogans. (2017). Retrieved September 09, 2017, from http://www.thinkslogans.com/ company/burger-king/

Eagle Boys Pizza Seeks Expansion In India. (2013, August 26). Retrieved September 10, 2017, from https://news.franchiseindia.com/Eagle-Boys-Pizza-seeks-expansion-in-India-2017

Eat Good And Feel Good. (2016, June 21). Retrieved September 09, 2017, from http://www.eatwithhop. com/2016/06/eat-good-and-feel-good-extreme-pita.html

Famous restaurant slogans and taglines. (2017). Retrieved August 09, 2017, from http://sloganshub.org/restaurants-slogans/

Fast Food Slogans List A - F. (2017). Retrieved July 23, 2017, from http://www.ffood. net/fast_food_slogans.htm

Fast food slogans. (2017). Retrieved September 01, 2017, from http $/ / \mathrm{w} w w . t e x t a r t . r u / a d v e r t i s i n g /$ slogans/fast-food.html

Fish and chips slogans. (2017). Retrieved June 12, 2017, from http://www.textart.ru/advertising/ slogans/fish-and-chips.html

Five Guys Prices. (2017, May 20). Retreived June 20, 2017, from https $/ /$ fastfoodinusa.com/five-guys-prices/ Hunt, Kristin. "10 things you didn't know about steak 'n shake" Thrillist. May, 2014. Retrieved July 10, 2017 from https://www.thrillist.com/eat/nation/a-brief-history-of-steak-n-shake

Manipulation. 2017. In Dictionary.com. Retrieved November 9, 2017, from http://www.dictionary. $\mathrm{com} / \mathrm{browse} / \mathrm{manipulation}$ ? $\mathrm{s}=\mathrm{t}$

Manipulation. 2017. In Oxford Learner's Dictionary. Retrieved November 9, 2017, from https://www.oxfordlearnersdictionaries.com/definition/english/manipulation?q=manipulation

Papa Murphy's Cowboy Pizza TV Commercial, 'Love at 425 Degrees. (2013). Retrieved August 09, 2017, from https://www. ispot.tv/ad/7d6y/papa-murphys-cowboy-pizza-love-at-425-degrees 
Perrotte, Ashley. “America' dinner is always open”. Prezi. Oct, 2015. Retrieved July 20, 2017, from https://prezi.com/vn99xnq6may_/americas-diner-is-always-open/

Pizza Hut. (2017). Retrieved August 11, 2017, from http://www.bestslogans.com/v/237117/makin-itgreat-again-and-again-pizza-hut/

Pret a manager. (2017). Retrieved June 09, 2017, from https://www.pinterest.com/pin/ $535013630709601320 /$

Rella, E. 'We're lovin' it: McDonald's slogans over the last five decades" Finance. Mar. 2016. Retrieved June 09, 2017, from https://www.aol.com/article/2016/03/01/were-lovin-itmcdonalds-slogans-over-the-last-five-decades/21320937/ https://genius.com/Fast-foodslogans-annotated

Restaurant Slogans. (2017). Retrieved August 09, 2017, from http://www.advergize.com/sloganslist/restaurant-slogans/

Restaurants. (2013, March 03). Retrieved June 03, 2017, from . http://www.morrisanderson.com/ resource-center/entry/Chains- last-links-Nostalgia-helps-keep-once-thriving-restaurantfranchises-/

Sarodh, Waiz. "Krispy Kreme: Slogans \& Humble Beginnings" Advergize Empowering Marketing, Mar. 2017. Retrieved August 09, 2017, from http://www.advergize.com/ advertising/krispy-kreme-slogans-and-humble-beginnings/

Smaktakula. "Commercials We Do Not Like: Bad Andy" Promethean Times. Feb. 2011. Retrie ved September 22, 2017, from https://prometheantimes.com/2011/02/22/commercialswe-do-not- like-badandy/

Smith, Nelson. "Boston Pizza: Sink Your Teeth into This Delicious 6\% Yield" Baystreet, May. 2017. Retrieved October 10, 2017, from http://www.baystreet.ca/dividends/159/BostonPizza-Sink-Your-Teeth-into-This-Delicious-6-Yield

Subway. (2017). Retrieved June 10, 2017, from http://slogans. wikia.com/wiki/Subway

10+ Wendy's Slogans Today, and Over the Years. (2017, June 8). Retrieved August 21, 2017, from http://www.advergize.com/advertising/10-wendys-slogans-today-years/

Wang, Eric. "McDonald's Slogans". Flickr. Nov. 2006. Retrieved November 01, 2017, from https://www.flickr.com/photos/99353402@N00/300852871/ 